\title{
Record of the freshwater stingrays Potamotrygon brachyura and $P$. motoro (Chondrichthyes, Potamotrygonidae) in the lower Uruguay River, South America
}

\author{
María Cristina ODDONE${ }^{1}$, Gonzalo VELASCO ${ }^{2}$ and Patricia $\mathrm{CHARVET}^{3}$
}

\section{ABSTRACT}

Freshwater stingrays, or potamotrygonids, are restricted to Neotropical river drainages. These elasmobranchs are well adapted to freshwater environments and the number of described species gradually increases as further research is carried out. Some of the first studies on their systematics and natural history were carried out in the 1960s and 1970s in southern South America. However, there is no new published data on potamotrygonids from Uruguayan waters since then (except for local journal reports from sportive fishermen and specimens deposited in Uruguayan collections). The present study aims to record the recent occurrence of two species of potamotrygonids caught by sport fishermen, with comments on other published historical records for the same area. As many other elasmobranchs, these species have an important, but not always well understood, role in the Uruguayan rivers ecosystems.

KEYWORDS: Potamotrygonidae, Nuevo Berlín, Paysandú, matrotrophy, potamotrygonid

\section{Registro das raias de água doce Potamotrygon brachyura e P. motoro (Potamotrygonidae) no Baixo Rio Uruguai, America do Sul}

\section{RESUMO}

As raias de água doce ou potamotrigonídeos estão restritas às drenagens dos rios Neotropicais. Estas raias tem se adaptado bem aos ambientes de água doce e o número de espécies descritas aumenta gradualmente conforme as pesquisas na área se intensificam. Alguns dos primeiros estudos sobre a sistemática e a historia natural deste grupo foram realizados nas décadas de 1960 e 1970 na região Sul de América do Sul. Porém, há poucos dados publicados sobre potamotrigonídeos em águas uruguaias desde então (com exceção de registros de pescadores esportivos publicados em jornais locais, e espécimes depositados em coleçóes uruguaias). O presente estudo, portanto, tem como objetivo registrar a ocorrência de duas espécies de potamotrigonídeos no Uruguai capturados por pescadores esportivos assim como realizar uma compilação de ocorrências anteriores presentes na literatura. Como muitos outros elasmobrânquios, estas espécies possuem um papel importante nos ecossistemas dos rios uruguaios, embora não completamente compreendido.

PALAVRAS-CHAVE: Potamotrygonidae, Nuevo Berlín, Paysandú, matrotrofia, potamotrigonídeo

\footnotetext{
1 Instituto de Ciências Biológicas, Universidade Federal de Rio Grande-FURG, Avenida Itália, km 8 s/n, Caixa Postal 474, 96201-900 Rio Grande, RS, Brazil, E-mail: cristina_oddone@ yahoo.com

2 Instituto de Oceanografia, Universidade Federal de Rio Grande-FURG, Avenida Itália, km 8 s/n, Caixa Postal 474, 96201-900 Rio Grande, RS, Brazil, E-mail: gonzalo.velasco.c@ gmail.com

${ }^{3}$ Gerência de Inovação, SENAI/DR/PR, Avenida Cândido de Abreu, 200, $3^{\circ}$ andar, Centro Cívico, 80530-902, Curitiba, PR, Brazil, E-mail: pchal@gmail.com
} 
The genus Potamotrygon Garman, 1877 (Family Potamotrygonidae Garman, 1877) comprises freshwater stingrays endemic to South American rivers of Argentina, Bolivia, Brazil, Colombia, French Guiana, Guyana, Paraguay, Peru, Suriname, Uruguay and Venezuela (Rosa 1985, Compagno 2005). The genus has thirty one nominal species of which 23 are possibly valid (Rosa et al. 2010). So far, most information on the habitat and ecology of freshwater stingrays comes from the Brazilian Amazon region but more studies are being pursued in other South American countries. It is known that $P$. motoro is a widely distributed, habitat generalist species (Rosa et al. 2010). Freshwater stingrays living usually on muddy bottoms have been already recorded, as well as over other diverse substrates, including sandy and rocky bottoms and all possible combinations (Charvet-Almeida 2006).

Although the presence of freshwater stingrays in Uruguayan rivers was previously confirmed, actual scientific records are scarce. Oddone et al. (2008) recorded the occurrence of specimens of the Shorttailed river stingray Potamotrygon brachyura (Günther 1880) in the Uruguay River and its tributaries in Paysandú, western Uruguay. The aim of the present study was to contribute to the knowledge of the distribution and life history of freshwater stingrays in the Uruguayan rivers with comments on these previous records and complementary data on the occurrence of two additional specimens caught in 2009.

Distribution patterns of freshwater stingrays in Uruguay are virtually unknown. In view of this, Oddone et al. (2008) carried out a survey based on newspaper records and on anecdotal data provided by local sport fishermen in the city of Paysandú (Uruguay) and also from the Argentinean side of the Uruguay River, specifically the province of Entre Ríos (Figure 1). The aim of the newspaper survey was bringing to

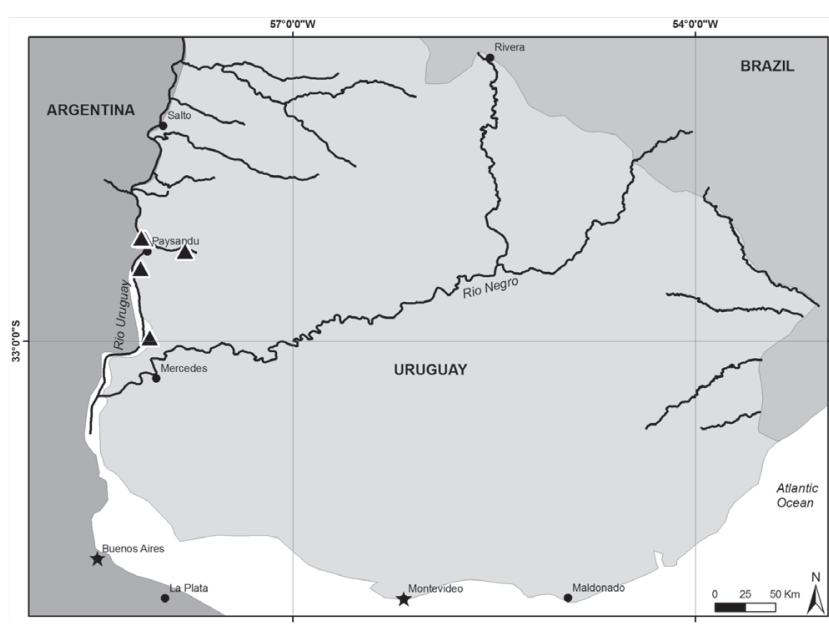

Figure 1 - Map of Uruguay showing the Uruguay River and its tributaries. Symbol indicates the capture sites for the six specimens considered. light anecdotal record of species occurrence from 1934 to 2004. Such anecdotal reports are actually the only published factual data available for freshwater stingrays from the area in question, apart from specimens deposited in collections. In addition, data on size (disc width), total weight, sex, date and local of occurrence were recorded. The fishing gear used in all these cases was hook and line or bottom-longline. Details on the bait historically used are unknown, but nowadays fishermen use mainly small Characiformes fishes or earthworms. Neither data on the depth of capture nor bottom characteristics were provided. Depth is mostly unknown by fishermen, and the river bottom is mostly muddy-sandy in the Uruguay River.

Regarding the complementary unpublished data, on February $28^{\text {th }} 2009$, two specimens of freshwater stingrays were accidentally caught by sport fishermen at the harbor of Nuevo Berlín, an Uruguayan settlement, in the Río Negro Department, on the shore of the Uruguay River, the natural border of the country with its neighbor, Argentina $\left(-32^{\circ} 58^{\prime}\right.$ $42^{\prime \prime} \mathrm{S}$ and $58^{\circ} 03^{\prime} 50^{\prime \prime} \mathrm{W}$, Figure 1). Fishermen contacted the authors soon after the caught providing information on the fishing site (geographical position, water temperature, depth) and photographs (Figures 2 and 3). The fishing gear used was hook and reel and the bait was corn, livestock heart and liver, and small fishes (Characiformes). Water temperature at the site was $25-30^{\circ} \mathrm{C}$, and the bottom was muddy with pebbles. At the time of the capture, the Uruguay River was flowing with the water level particularly low due to a drought. Stingrays were caught at a distance of $-50 \mathrm{~m}$ from the shore, at depths ranging between seven and $10 \mathrm{~m}$. Disc width $(\mathrm{cm})$ was recorded with the aid of a measuring tape. Total weight (g) was estimated

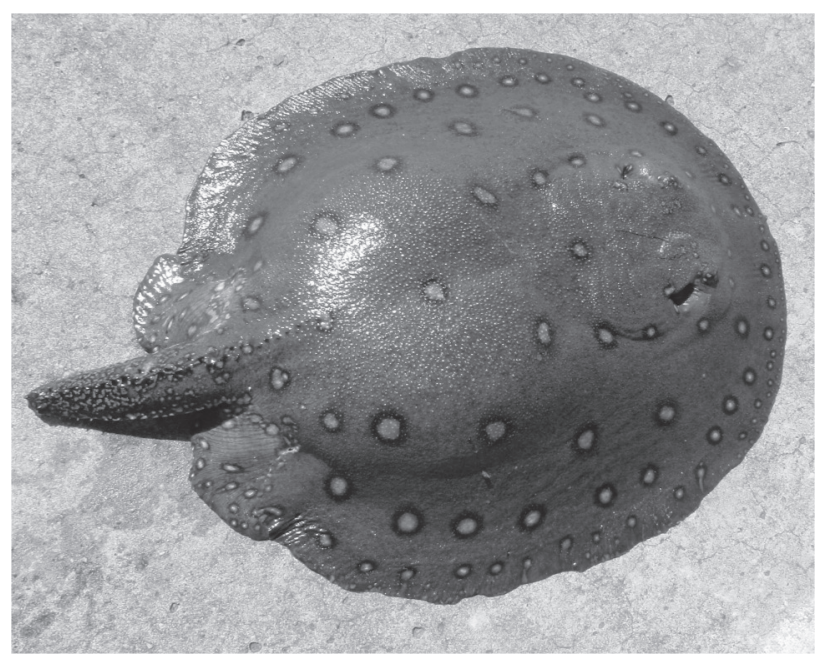

Figure 2 - Pregnant female of Potamotrygon motoro with total disc width of $52 \mathrm{~cm}$ and total weight of $4 \mathrm{~kg}$ captured at the Nuevo Berlín harbor, Río Negro Department, Uruguay, shore of the Uruguay River $\left(\sim 32^{\circ} 58^{\prime} 60^{\prime \prime} \mathrm{S}\right.$ and $58^{\circ} 2^{\prime}$ $60 " W)$ on February 28th, 2009, with hook and reel. 


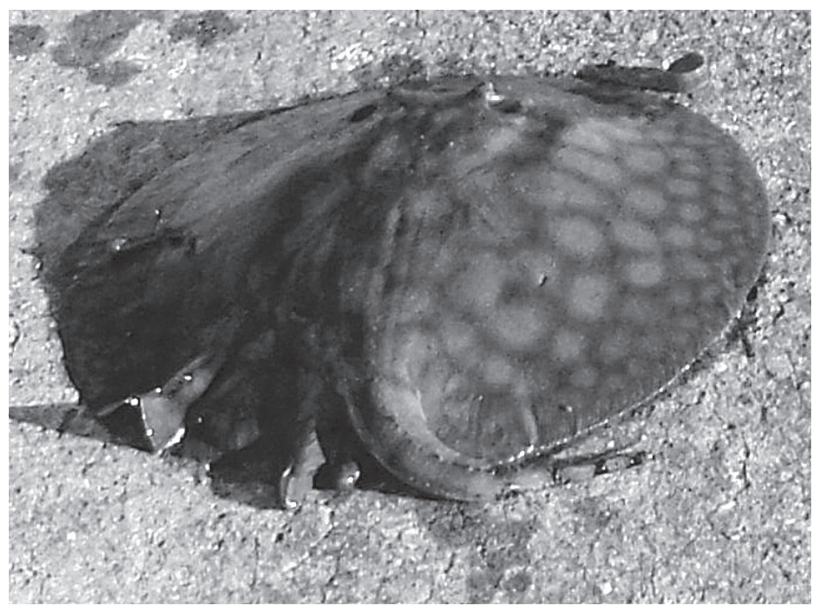

Figure 3 - Subadult male of Potamotrygon brachyura with total disc width of $42 \mathrm{~cm}$ and total weight of $3 \mathrm{~kg}$ captured at the Nuevo Berlín harbor, Río Negro Department, Uruguay, shore of the Uruguay River $\left(\sim 32^{\circ} 58^{\prime} 60^{\prime \prime} S\right.$ and $58^{\circ} 2^{\prime}$ 60 "W) on February 28th, 2009, with hook and reel. by the fishermen as no scale was available at the time. Sex and maturity stage (assessed by external characteristics) were inferred through the photographs, sensu Castex (1963), Castex and Maciel (1965) and Achenbach and Achenbach (1976). Specimens were returned alive to the stream, for this reason further biological sampling did not take place.

A total of six specimens of potamotrygonids were recorded for this region (Table 1). The specimens were identified as Potamotrygon brachyura (specimens \#1 to \#5) and P. motoro (specimen \#6) considering their dorsal coloration pattern and, mainly, body morphology and dimensions, according to Castex (1963) and Rosa et al. (2010).

Regarding the additional data, the first specimen of these new records (\#5), was a sub adult male with $3.0 \mathrm{~kg}$ of TW and $42.0 \mathrm{~cm}$ of DW (Figure 2). In this specimen, the claspers were elongated and flexible indicating the transitional stage from juvenile to adult. The second one (\#6) was a female specimen of $P$. motoro with $4.0 \mathrm{~kg} \mathrm{TW}$ and $52.0 \mathrm{~cm} \mathrm{DW}$, pregnant and probably near term (Figure 3 ).

Table 1 - Data on the specimens of freshwater stingrays collected in the Uruguay River, Uruguay, South America. Specimen number (\#), species, locality (fishing site), geographical coordinates (latitude and longitude), date, total weight (g), total width (cm), fishing gear used and observations (when available).

\begin{tabular}{|c|c|c|c|c|c|c|c|c|c|}
\hline Specimen \# & Species & Locality & $\begin{array}{l}\text { Approximate } \\
\text { geographical } \\
\text { coordinate }\end{array}$ & Date & $\begin{array}{c}\text { Total } \\
\text { weight } \\
\text { (kg) }\end{array}$ & $\begin{array}{l}\text { Disc } \\
\text { width } \\
\text { (cm) }\end{array}$ & Sex & $\begin{array}{l}\text { Fishing } \\
\text { gear }\end{array}$ & Observations \\
\hline 1 & P. brachyura & $\begin{array}{l}\text { San Francisco Stream, } \\
\text { mouth of the Uruguay } \\
\text { River, Diecinueve de } \\
\text { Abril town, city of } \\
\text { Paysandú, Uruguay }\end{array}$ & $\begin{array}{l}32^{\circ} 14^{\prime} 25^{\prime \prime} \mathrm{S} \\
58^{\circ} 05^{\prime} 54^{\prime \prime W}\end{array}$ & 1934 & 120 & 150 & unknown & unknown & - \\
\hline 2 & P. brachyura & $\begin{array}{l}\text { mouth of the San } \\
\text { Francisco Stream, } \\
\text { Uruguay River, } \\
\text { Uruguay }\end{array}$ & $\begin{array}{l}32^{\circ} 14^{\prime} 25^{\prime \prime S} \\
58^{\circ} 05^{\prime} 54^{\prime \prime W}\end{array}$ & 1998 & 50 & 103 & unknown & $\begin{array}{l}\text { hook and } \\
\text { line }\end{array}$ & - \\
\hline 3 & P. brachyura & $\begin{array}{l}\text { Caraballo Stream } \\
\text { (Argentinean shore of } \\
\text { the Uruguay River), } \\
\text { across from Paysandú } \\
\text { City) }\end{array}$ & $\begin{array}{l}32^{\circ} 14^{\prime} 06^{\prime \prime} \mathrm{S} \\
58^{\circ} 07^{\prime} 28^{\prime \prime} \mathrm{W}\end{array}$ & $\begin{array}{c}\text { January } \\
2001\end{array}$ & 114 & 110 & male & long-line & $\begin{array}{l}\text { The Uruguay River } \\
\text { was over } 1.5 \mathrm{~m} \\
\text { above the mean } \\
\text { level for the season, } \\
\text { due to the release } \\
\text { of water from } \\
\text { the Salto Grande } \\
\text { hydroelectrical } \\
\text { dam, some } 80 \mathrm{~km} \\
\text { upstream }\end{array}$ \\
\hline 4 & P. brachyura & $\begin{array}{l}\text { Negro Stream, } \\
\text { southern Paysandú, } \\
\text { Uruguay }\end{array}$ & $\begin{array}{l}32^{\circ} 27^{\prime} 40^{\prime \prime} \mathrm{S} \\
58^{\circ} 07^{\prime} 49^{\prime \prime} \mathrm{W}\end{array}$ & $\begin{array}{c}\text { October } 26 \\
2004\end{array}$ & 11 & 80 & female & $\begin{array}{l}\text { hook and } \\
\text { line }\end{array}$ & - \\
\hline 5 & P. brachyura & $\begin{array}{l}\text { harbor of Nuevo } \\
\text { Berlín, Río Negro } \\
\text { Department, Uruguay }\end{array}$ & $\begin{array}{c}32^{\circ} 58^{\prime} 60^{\prime \prime} S \text { and } \\
58^{\circ} 2^{\prime} 60^{\prime \prime} W\end{array}$ & $\begin{array}{l}\text { February } \\
282009\end{array}$ & 3 & 42 & male & $\begin{array}{l}\text { hook and } \\
\text { reel }\end{array}$ & $\begin{array}{l}\text { subadult specimen, } \\
\text { bait was corn, } \\
\text { livestok heart and } \\
\text { liver and small fishes }\end{array}$ \\
\hline 6 & P. motoro & $\begin{array}{l}\text { harbor of Nuevo } \\
\text { Berlín, Río Negro } \\
\text { Department, Uruguay }\end{array}$ & $\begin{array}{c}32^{\circ} 58^{\prime} 60^{\prime \prime} \text { S and } \\
58^{\circ} 2^{\prime} 60^{\prime \prime} W\end{array}$ & $\begin{array}{l}\text { February } \\
282009\end{array}$ & 4 & 52 & female & $\begin{array}{l}\text { hook and } \\
\text { reel }\end{array}$ & $\begin{array}{l}\text { Pregnant (near term), } \\
\text { tail cut off, bait was } \\
\text { corn, livestok heart } \\
\text { and liver and small } \\
\text { fishes }\end{array}$ \\
\hline
\end{tabular}


Gestation in freshwater stingrays can be easily detected externally when close to term (P. Charvet, pers. obs.). The reproductive mode observed so far in potamotrygonids is lipidic histotrophy, a kind of matrotrophic viviparity (CharvetAlmeida 2001, 2006). A uterine fecundity of 21 pups per litter was previously recorded for $P$. motoro (Almeida 2008). This is the highest value recorded for freshwater stingrays. For P. brachyura, Achenbach and Achenbach (1976) reported a uterine fecundity of 19 embryos.

The fact that fishermen returned the specimen to the river may have important conservational implications. An ongoing project with these fishes carried out in Uruguay by the authors, aims to encourage sport fishermen to do so. Several species of freshwater stingrays have their reproductive cycles associated with the hydrologic cycle of each region or river basin (e.g., Achenbach and Achenbach 1976; CharvetAlmeida et al. 2005; Rincon 2006). Since this can make them more vulnerable in some specific periods, catch and release is to be encouraged.

Specimens \#2, \#5 and \#6, had their tail cut off and well healed (Figure 2 and Figure 4 in Oddone et al. 2008). This practice by fishermen is commonly seen in freshwater stingrays and is due to negative fishery. Mutilated potamotrygonids have already been recorded for other areas and the reasons for this practice are related to the painful wounds they may cause with the sting (Charvet 2006, Rincon 2006). Because of the potential danger to people, they represent, they are either killed or discarded having their stings removed or even their tails cut off before release (Compagno 1990; Compagno and Cook 1985), as in these two cases, here reported.

Freshwater stingrays are exported for ornamental purposes from several South American countries and so far, Brazil is the only one having specific regulations for the exportation of these species (Rosa et al. 2010). In Uruguay, freshwater stingrays have traditionally not been studied, and because of this, ornamental practices have never been previously reported. No regulations regarding freshwater stingrays traffic and/or exportation exist in Uruguay, as the status of the population is completely unknown. Potamotrygon motoro and P. brachyura are currently listed in the IUCN Red List of Threatened Species as Data Deficient (Charvet-Almeida et al. 2003; Drioli and Chiaramonte 2005). For these reasons, urgent monitoring of the regional fisheries is recommended, altogether with sampling programs in order to gather data on the distribution, abundance and life history of Potamotrygon spp. in Uruguay.

\section{ACKNOWLEDGEMENTS}

Authors are thankful to sport fisherman Álvaro Etchegaray, to journalist Andrés Oberti ("El Telégrafo" newspaper, Paysandú, Uruguay) and to Camilla V. Thomas Bastianon who provided Figure 1. The data presented here corresponds to preliminary results of Project "POTAMO", a bi-national research project devoted to understanding potamotrygonid biology ecology and conservation in the Uruguay River.

\section{REFERENCES}

Achenbach, G.M.; Achenbach, S.V.M. 1976. Notas acerca de algunas especies de raya fluvial (Batoidei, Potamotrygonidae), que frecuentan el sistema hidrográfico del río Paraná medio en el Departamento La Capital (Santa Fe-Argentina). Comunicaciones del Museo Provincial de Ciencias Naturales Florentino Ameghino, 8: $1-34$.

Almeida, M.P. 2008. Natural history of freshwater stingrays (Chondrichthyes: Potamotrygonidae) in Marajó Island (ParáBrasil). Dissertação de Mestrado, Universidade Federal do Pará, Belém. 145 pp. (In Portuguese).

Castex, M.N. 1963. Observaciones sobre la raya de río Potamotrygon motoro (Müller y Henle). Comunicaciones del Museo Argentino de Ciencias Naturales Bernardino Rivadavia, Hidrobiologia, 1 (2): 7-14.

Castex, M.N.; Maciel, I.M. 1965. Notas sobre la familia Potamotrygonidae Garman 1913. Santa Fé, Dirección General de Recursos Naturales, Publicacion Tecnica, 14: 1 - 23.

Charvet-Almeida, P. 2001. Ocurrence, biology and use of freshwater stingrays in the Marajó Bay (Pará, Brasil), with focus in the biology of Plesiotrygon iwamae (Chondrichthyes: Potamotrygonidae). Dissertação de Mestrado, Universidade Federal do Pará, Belém. 213 pp. (In Portuguese).

Charvet-Almeida, P. 2006. Natural history and conservation of freshwater stingrays (Chondrichthyes: Potamotrygonidae) in Xingu River, influence area of the hydroelectric Project of Belo Monte (Pará, Brasil). Tese de doutorado, Universidade Federal da Paraíba, João Pessoa. 475 pp. (In Portuguese).

Charvet-Almeida, P.; Soto, J.M.R.; Almeida, M.P. 2003. Potamotrygon brachyura (www.iucnredlist.org/apps/redlist/details/161687/0). Acesso em 17/06/10.

Charvet-Almeida P; Araújo M.L.G.; Almeida, M.P. 2005. Reproductive aspects of freshwater stingrays (Chondrichthyes: Potamotrygonidae) in the Brazilian Amazon Basin. Journal of the Northwest Atlantic Fishery Science, 35: 165-171.

Compagno, L.J.V. 1990. Shark exploration and conservation, p. 391-414. In: Pratt, H.L.; Gruber, S.H.; Taniuchi, T. (Eds). Elasmobranch as Living Resources: advances in biology, ecology and systematics, and the status of fisheries. NOAA Technical Report NMFS, USA. 
Compagno, L.J.V.; Cook, S.F. 1995. The exploitation and conservation of freshwater elasmobranchs: status of taxa and prospects for the future. p. 62-90. In: Oetinger, M. I.; Zorzi, G. D. (Eds.) The Biology of Freshwater Elasmobranchs. Journal of Aquariculture and Aquatic Sciences 7: 62 - 90.

Compagno, L.J.V. 2005. Checklist of living Chondrichthyes, p. 503-548. In. Hamlett, W.C. (Ed). Reproductive biology and phylogeny of Chondrichthyes, sharks, batoids and chimaeras. Science Publishers, Inc. Enfield (NH), USA.

Driolo, M.; Chiaramonte, G. 2005. Potamotrygon motoro. In: IUCN 2010. IUCN Red List of Threatened Species (www.iucnredlist. org/apps/redlist/details/161687/0). Acesso em 17/06/2010.

Oddone, M.C.; Velasco, G.; Rincon, G. 2008. Occurrence of freshwater stingrays (Chondrichthyes: Potamotrygonidae) in the Uruguay River and its tributaries, Uruguay, South America. Aqua International Journal of Ichthyology, 14: 214.
Rincon, G. 2006. Taxonomical aspects, diet and reproduction of the freshwater stingrays Potamotrygon orbignyi (Castelnau) (Elasmobranchii: Potamotrygonidae) in River Paraná-Tocantins. PhD Thesis, Universidade Estadual Paulista, Rio Claro. 132 pp. (In Portuguese).

Rosa, R.S. 1985. A systematic revision of the South American freshwater stingrays (Chondrichthyes: Potamotrygonidae). PhD Thesis, Williamsburg, College of William and Mary. 523 pp.

Rosa, R.S.; Charvet-Almeida, P.; Quijada, C.C.D. 2010. Biology of the South American Potamotrygonid Stingrays, p. 241-285. In: Carrier, J.C., Musick, J.A., Heithaus, M.R.. Sharks and Their Relatives II: Biodiversity, Adaptive Physiology, and Conservation. CRC Press, Boca Raton, USA.

Recebido em 03/02/2011

Aceito em 17/04/2011 
